\title{
Beyond Politeness: The Expression of Gratitude in Children and Adolescents
}

\author{
Além da Polidez: A Expressão de Gratidão em Crianças e Adolescentes
}

\author{
Lia Beatriz de Lucca Freitas*, ${ }^{*}$, Maria Adélia Minghelli Pieta ${ }^{a}$ \\ \& Jonathan Richard Henry Tudge ${ }^{b}$ \\ ${ }^{a}$ Universidade Federal do Rio Grande do Sul, Porto Alegre, Brasil \\ $\&{ }^{b}$ University of North Carolina, Greensboro, USA
}

\begin{abstract}
We present results from a study about the expression of gratitude in children and adolescents. Four hundred and thirty children, aged 7 to 14 years old (58\% female), answered the questions: "What is your greatest wish?" and "What would you do for the person who granted you this wish?" The responses to the second question were content-analyzed and coded into four types of gratitude: verbal, concrete, connective and finalistic. Subsequently we conducted a quantitative analysis regarding age by each type of response. The results show a decline in the frequency of concrete gratitude and an increase in connective gratitude as respondents' age increases. The results - discussed with reference to the current literature suggest questions for new research.

Keywords: Gratitude; Development; Children; Adolescents.

Resumo

Apresentam-se resultados de um estudo sobre a expressão da gratidão em crianças e adolescentes. Quatrocentas e trinta crianças e adolescentes, de 7 a 14 anos (58\% do sexo feminino) responderam às perguntas: "O que tu mais queres?" e "O que tu farias para a pessoa que te desse o que tu mais queres?". As respostas dos participantes à segunda pergunta foram submetidas à análise de conteúdo, considerandose quatro tipos de gratidão: verbal, concreta, conectiva e finalistica. A seguir, realizou-se uma análise da frequência das categorias nas diferentes idades. Verificou-se um decréscimo na frequência de gratidão concreta com o avanço da idade e um aumento do tipo conectiva. Os resultados, discutidos à luz da literatura, sugerem questões para novas pesquisas.

Palavras-chave: Gratidão; Desenvolvimento; Crianças; Adolescentes.
\end{abstract}

Gratitude seems to benefit society, as well as contribute to subjective well-being. Adam Smith (1759/2002) considered gratitude as one of the main drivers of benevolence and, thus, a major feeling that helps ensure a society's stability, founded on good will. Baumgarten-Tramer (1938) considered gratitude as being responsible for social cohesion, since it creates a relationship among people, developing their sense of community. The results of Algoe, Haidt and Gable's (2008) study indicate that gratitude's aim is creating and maintaining bonds.

Simmel (1950) defined gratitude as the "moral memory of mankind": due to insufficient formal social structures that ensure reciprocity in interactions with others, human beings learn to experience gratitude as a way not to forget

"Address: Universidade Federal do Rio Grande do Sul, Instituto de Psicologia, Departamento de Psicologia do Desenvolvimento e da Personalidade, Rua Ramiro Barcelos, 2600, sala 118, Santana, Porto Alegre, RS, Brazil, CEP 90035-003. E-mail: lblf@ufrgs.br

This research was supported by Capes Foundation, Ministry of Education, Brazil. reciprocity of obligations. For Simmel, gratitude is one of the moral feelings that binds individuals to society. Gratitude seems to be a crucial element of reciprocity (Bowles \& Gintis, 2004; Gintis, 2000), that is, the predisposition of individuals to cooperate with others or to punish (for example, with ostracism) those who do not cooperate (Gintis, Bowles, Boyd, \& Fehr, 2005).

According to Piaget (1965/1977), the preservation of society requires social exchanges that provide reciprocal benefits. However, the qualitative values produced in the day-to-day exchanges (for example, the satisfaction felt towards a received favor) tend to crumble in the absence of rules to preserve them. Because of this, every society counts on a set of operations (devices) to preserve its values, which ensures the qualitative equivalence of the exchanged values, regardless of personal interest, social class, and so on. Morality is, according to Piaget, one of these devices that conserve such values over time, and such conservation is crucial to social life.

Besides contributing to the maintenance of reciprocal social exchanges and interpersonal bonds, gratitude also 
adds to individuals' feelings of well-being and to their quality of life (e.g., Bono \& McCullough, 2006; Sheldon $\&$ Lyubomirsky, 2006). Research conducted with adults indicates that individuals who express more gratitude have higher levels of happiness and lower depression and stress levels (McCullough, Tsang, \& Emmons, 2004; Miller, 2006; Watkins, Woodward, Stone, \& Kolts, 2003). Individuals who express gratitude, when compared to those who do not express it, appear more optimistic, like their jobs more and appear to be more inclined to help and support others (Bartlett \& DeSteno, 2006; Froh, Miller, \& Snyder, 2007; Tsang, 2006, 2007). Studies indicate that the conscious practice of experiencing and expressing gratitude is a feasible way in which to increase subjective well-being (Lyubomirsky, Sheldon, \& Schkade, 2005; Seligman, Steen, Park, \& Peterson, 2005; Sheldon \& Lyubomirsky, 2006). Although most research has been conducted with adults (Froh, 2010; Pieta \& Freitas, 2009), some studies indicate that gratitude can also contribute to the promotion of youths' well-being (Froh, Kashdan, Ozimkowski, \& Miller, 2009) and is associated with success at school (Bono \& Froh, 2009).

As a result of the evidence of its benefits, it is thought that gratitude should be cultivated since childhood. Empirical research indicates that children and adolescents are able to understand (Freitas, Silveira, \& Pieta, 2009a, 2009b; Graham \& Barker, 1990; Harris, Olthof, Meerum Terwogt, \& Hardman, 1987; La Taille, 1998; Russell \& Paris, 1994) as well as to experience and to express gratitude (Baumgarten-Tramer, 1938; Becker \& Smenner, 1986; Gordon, Musher-Eizenman, Holub, \& Dalrymple, 2004; Paludo, 2008). However, as Emmons and Shelton (2002) emphasized, gratitude "does not emerge spontaneously in newborns" (p. 468), but it is formed throughout development by the interaction of the child with individuals who participate in his or her social environment. However, as other authors have previously pointed out (Bono \& Froh, 2009; Froh et al., 2007), few empirical studies with children and adolescents have been conducted, and gratitude's developmental trajectory remains unknown.

The development of gratitude in childhood and adolescence. For Emmons and Shelton (2002), studies on the emergence of gratitude in children is a critical priority. Still awaiting investigation are issues such as whether gratitude varies by age, if it is experienced and expressed in different ways by boys and girls, if it can be stimulated and how it influences psychological functioning.

In his search of the scientific database PsycInfo, Froh (2010) found the following data: in the period between 1887 and 1998, from a total of 218 articles, 42 were on children and 5 on adolescents; from 1999 to the time of writing, from a total of 638 articles, 74 were on children and 19 on adolescents. A significant increase in the number of articles on gratitude could be observed. Nonetheless, studies of children and adolescents have not grown at the same ratio.
Among the relatively small number of empirical studies on gratitude, that by Baumgarten-Tramer (1938) stands out. She posed two questions to children and adolescents from Bern, Switzerland: (a) "What is your greatest wish?" and (b) "What would you do for the person who granted you this wish?" Baumgarten-Tramer found differences in the way children and adolescents expressed gratitude, and defined four types of gratitude. She also found that the frequencies of these different types varied according to the age of the participants.

Verbal gratefulness, of the "thank you" kind, can simply reflect what the child has been taught to say, without necessarily denoting a feeling of gratitude. La Taille (2001) observed the same tendency in his study of politeness in children. However, according to BaumgartenTramer (1938), verbal gratitude could also be used when the child feels profound gratitude, but does not know how to express what he or she feels. Verbal gratitude was found with equal frequency among children from 7 to 14 years of age (on average, $30 \%$ to $40 \%$ of the answers).

Concrete gratitude appears when children repay with something valuable for themselves, but not necessarily valuable for the benefactor, which reflects the egocentric nature of this kind of gratitude. Concrete gratefulness appeared more frequently in 8 -year-old children $(51 \%)$ and more rarely in participants from 12 - to 15 -year-olds $(6 \%)$.

Connective gratitude is characterized by the creation of a spiritual relationship with the benefactor. In this case, repayment is either something of value to the benefactor or the expression of feelings, such as honoring the benefactor or considering him or her a great friend. Repayment intended to benefit society also appears, in a mark of altruism. This type of gratitude was significantly more likely to be expressed by children older than 11 years, being most frequent in 12-year-olds $(60 \%)$.

Baumgarten-Tramer (1938) named the fourth type of gratitude "finalistic" to denote situations in which children repay a favor either with an action that assists in the attainment of the object or desired situation, or with an action that promotes their own personal development. She illustrated this type with answers of 14-year-olds, such as the adolescent who chose as his or her greatest wish to get a job, and says that he or she would repay the person who made this job possible by being punctual and honest at work. Baumgarten-Tramer did not indicate the frequency of finalistic gratitude found in her sample. Tsang and McCullough (2004) called attention to the importance of Baumgarten-Tramer's pioneering study (1938), in particular the relevance of her results and her impressive theorizing. Moreover, as Froh et al. (2007) pointed out, this study was the "the only known attempt at scientifically elucidating the developmental trajectory and manifestation of gratitude in children and adolescents" (p. 4). There is also the fact that elucidating the distinction between politeness and a true feeling of gratitude has been one of the major challenges faced by researchers who 
conduct studies with children (Bono \& Froh, 2009; Gordon et al., 2004). Baumgarten-Tramer's method led to results that sharpened this distinction. We therefore decided to replicate Baumgarten-Tramer's study in a different context and at a different historical time.

The starting point for this study was BaumgartenTramer's research (1938), and it was inspired by Piaget's (1954) hypothesis that gratitude developed throughout childhood. According to Piaget, children's capacity to evoke an experienced satisfaction, and their acquired ability to conserve this experience over time, is essential for such development. Both Baumgarten-Tramer and Piaget considered gratitude to be an interindividual feeling, i.e., arising from relations with others (Freitas, 1999).

Piaget (1932/1992) did not conduct any empirical research on gratitude, but investigated other interindividual feelings, which are important for the establishment of human morality - respect and the feeling of obligation or duty - and showed, in his research, that these feelings develop (Freitas, 2003). Moreover, Piaget (1965/1977) proposed a model to explain social exchanges of values, which would also explain gratitude. This model is important to understand what occurs, at a psychological level, between beneficiary and benefactor, especially the conditions under which a beneficiary feels a symbolic debt (a debt of gratitude) towards a benefactor, and the need to repay the favor (for further information see Castro, Rava, Hoefelmann, Pieta, \& Freitas, 2011; Freitas et al., 2009a, 2009b).

It is also important to recognize that Piaget (1932/1992) stated that the norm of reciprocity implies "positive obligations" (p. 185) and not only those negative duties (for example, neither lying nor stealing) that he investigated. This observation of Piaget opens new ways to study the so-called positive duties (for further information see La Taille, 2006; Lourenço, 2000) and, thus contributes to the expansion of the field of investigation into moral psychology.

This paper presents a study on the expression of gratitude in children and adolescents from Porto Alegre/RS. It is based on Baumgarten-Tramer's (1938) view that the way in which gratitude is expressed develops between 7 and 14 years of age, specifically from concrete gratitude to connective gratitude.

\section{Method}

\section{Participants}

Participants consisted of 430 children and adolescents from 7 to 14 years (mean age $=10.8$; standard deviation $=2.1$ ), 181 males and 249 females. The sample was one of convenience, drawing on two public schools and two private schools in Porto Alegre - RS: $62.1 \%$ of the participants were from public schools and $37.9 \%$ from private schools. The participants were between the $2^{\text {nd }}$ and $8^{\text {th }}$ grades of elementary school. In schools where there was more than one class for each grade, the choice for the participating class was randomized.

\section{Material and Procedures}

Two questions from Baumgarten-Tramer's (1938) study were used, having been translated into Portuguese: "What is your greatest wish?" and "What would you do for the person who granted you this wish?" During the translation process for these questions, some versions were read to the children, who made suggestions for changes in the wording. That version was used in a pilot study with 10 children and, as it was easy to understand, was retained until the end of the study.

The participants received the questions in printed form on a sheet of paper. An initial rapport was established, during which the participants were informed of the procedures to be followed in order to answer the questions. They were also told that they could choose to participate or not in the study, and that they could leave the study if they wished. The questions were posed collectively in a classroom of the school in which the participants studied. When all of them had finished answering the questions, the sheets were collected and a quick check was carried out. In case an answer was not clear, the participant was asked to explain its meaning, which was written down. The whole process lasted around 30 minutes. No instrument remained incomplete. Each school board signed a document authorizing the study. The parents or guardians of the participants signed a Free and Clarified Consent Form.

We conducted a content analysis on the answers to the question "What would you do for the person who granted you this wish?" taking into account the four kinds of gratitude defined by Baumgarten-Tramer (1938). Two judges worked independently to code the answers: one of the judges read and coded all the answers and the other read and coded $18.8 \%$ of the answers. Interrater reliability, using Kappa, was .95. Next, a quantitative analysis of the frequency of categories provided by participants of different ages was performed, using chi-square.

\section{Results}

Initially, we analyzed the types of gratitude present in the answers of each participant according to BaumgartenTramer's (1938) categories. For instance, the following answers were classified as verbal gratitude: "I would say thank you;" "I would thank all the time, always;" "I would be grateful forever and would thank a lot." The following answers were classified as concrete gratefulness: "I would give a present, I would hug and kiss," "I would give a car;" "shoes, purse, make-up, a coat, and earrings;" "one million dollars." Some examples of connective gratitude were: "I would reward with something that the person wants a lot;" "for this person I would give friendship, respect, etc.;" "I would be cool with that person;" "I would 
give anything possible that he or she asks of me." The finalistic gratitude appeared as follows: "I will study a lot, make an effort in swimming;" "I would repay with all my effort as a professional football player." In several answers, more than one kind of gratitude was identified. Categories were recorded both when they appeared alone (for example, only "verbal") and when they appeared together with other categories. For example, if a participant wrote: "I would give a kiss" and "I would be a close friend of this person", his or her answer was classified as concrete and connective gratitude, respectively. "Other" answers were understood as those that could not be classified into any of the four categories defined by Baumgarten-Tramer. For example, a girl wrote "Isplicar" [sic "Ecksplain"], that is, explain what she wanted the most, so that the person could give her the desired object. The category "Other" also included those cases in which the participants wrote "I don't know." Table 1 displays the results of the frequency associated to types of gratitude.

Table 1

Frequency and Percentage of Gratitude Types per Age

\begin{tabular}{lrrrrrrrrrrr}
\hline \multirow{2}{*}{ Category } & \multicolumn{1}{c}{ Age } & & \multirow{2}{*}{$N$} & $\%$ \\
\cline { 2 - 8 } & 7 & 8 & 9 & 10 & 11 & 12 & 13 & 14 & & \\
\hline Verbal (V) & 8 & 12 & 12 & 15 & 13 & 24 & 6 & 14 & 104 & 24.2 \\
Concrete (CT) & 17 & 19 & 14 & 7 & 4 & 1 & 2 & 0 & 64 & 14.9 \\
Connective (CV) & 5 & 14 & 17 & 15 & 15 & 9 & 13 & 5 & 93 & 21.6 \\
V + CT & 4 & 7 & 8 & 7 & 1 & 5 & 4 & 1 & 37 & 8.6 \\
V + CV & 0 & 2 & 7 & 14 & 14 & 11 & 13 & 7 & 68 & 15.8 \\
CT + CV & 1 & 1 & 1 & 0 & 3 & 0 & 3 & 0 & 9 & 2.1 \\
V + CT + CV & 1 & 1 & 0 & 2 & 2 & 1 & 0 & 1 & 8 & 1.9 \\
Finalistic & 0 & 0 & 0 & 0 & 0 & 0 & 2 & 0 & 2 & 0.5 \\
Other & 6 & 2 & 3 & 8 & 6 & 7 & 11 & 2 & 45 & 10.4 \\
Total & 42 & 58 & 62 & 68 & 58 & 58 & 54 & 30 & 430 & 100.0 \\
\hline
\end{tabular}

Only $3 \%$ of the participants answered "I don't know" and $7.4 \%$ of the answers could not be classified according to Baumgarten-Tramer's categories (1938). These cases and two answers classified as finalistic gratitude were excluded from the statistical analysis.

Next, the most developed kind of gratitude was defined in the answers of each participant. The following types were considered in ascending order: (a) verbal, (b) concrete and (c) connective. As can be seen in Figure 1, with age there was a decrease in the frequency in concrete gratitude and an increase in both verbal and connective gratitude. The relation between age and type of gratitude was significant $\left(\chi^{2}(14)=77.3, p<.001\right)$.

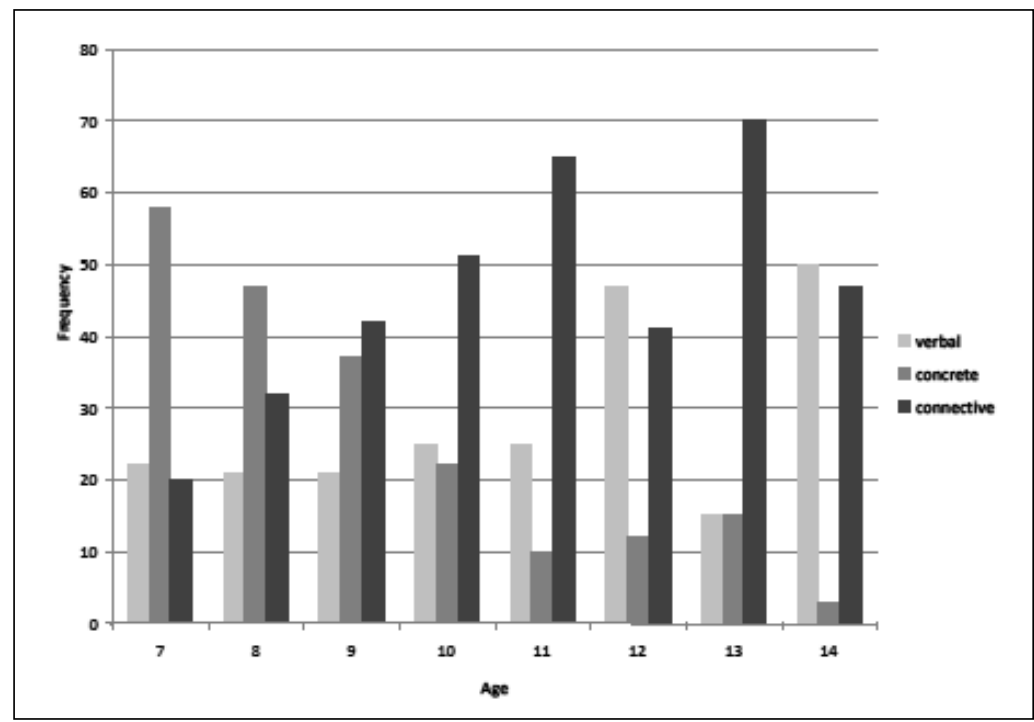

Figure 1. Percentage, by age, of the most developed types of gratitude. 
For the purposes of clarity and a more appropriate test of the relation between age and type of gratitude, the participants were placed into one of two age-groups (from 7 to 10 years and from 11 to 14 years). Since girls and boys did not differ significantly concerning the types of gratitude $\left(\chi^{2}(2)=.73, \mathrm{~ns}\right)$, the data of both genders were analyzed together. Figure 2 shows the same data, by age group.

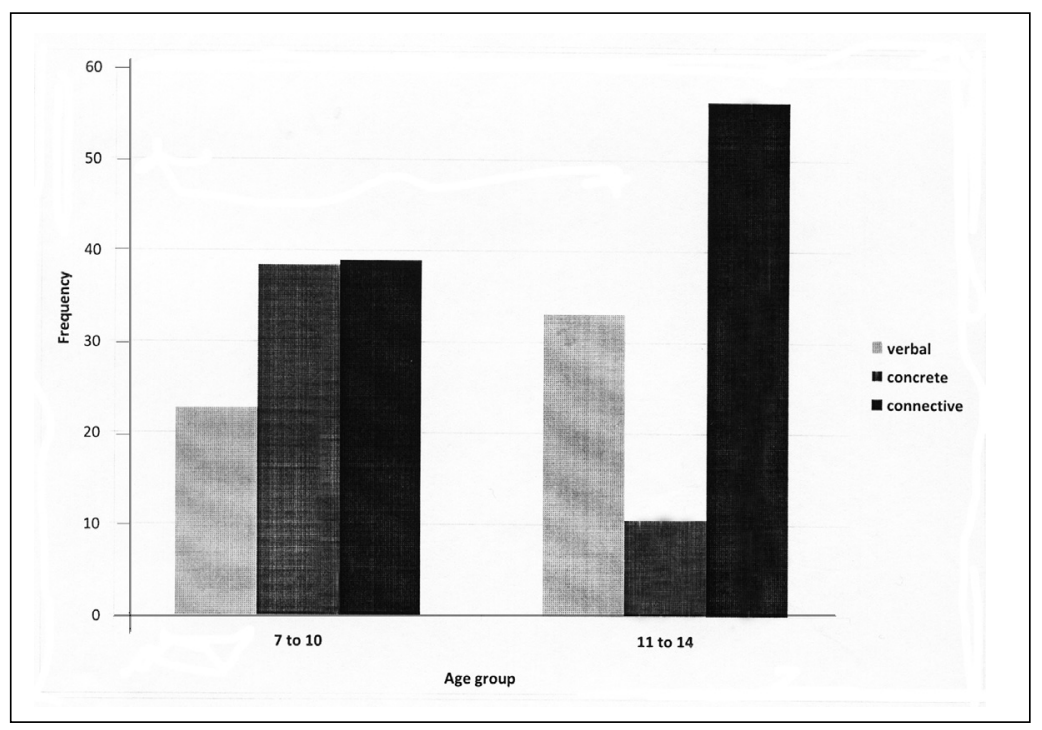

Figure 2. Percentage, by age group, of the most developed types of gratitude.

The results are very similar to those already presented. The relation between age group and type of gratitude was significant: $\chi^{2}(2)=39.61, p<.001$. Although there was a slight increase in the frequency of verbal gratitude with age, the relation between age group and this kind of gratitude was not significant, $\chi^{2}(1)=.77$, ns. The difference between age groups is due to the decrease in concrete gratitude and to the increase of connective gratitude in the older group: $\chi^{2}(1)=35.16, p<.001$.

Analyzing the answers classified as "Other" $(7.4 \%$ of the total cases), two recurring themes were observed. The first is that in $25 \%$ of the answers the participants mentioned positive feelings: (a) towards the benefactor's action $(6.2 \%)$; (b) towards the benefactor himself or herself (3.1\%); or (c) expressed positive feelings without mentioning either the benevolent action or the benefactor (15.6\%). For example: "I would be very happy if she gave me the bicycle" (related to the benevolent action); "I would be very happy with her, etc." (referring to the benefactor); "I would be happy" (without mentioning the benevolent action or the benefactor). The second is that, among children older than 10 years the idea of selfsufficiency appeared; that is, that the individual should obtain what he or she desires by him- or herself. Selfsufficiency appeared in answers of $8.6 \%$ of the participants, sometimes in conjunction with responses that could be classified according to Baumgarten-Tramer's (1938) categories. For example, a 14-year-old girl said that her greatest wish was to be someone with character and education. She answered to the second question: "I would do anything that this person wanted, but only I can do this; someone might help me, but no one can do it for me. Building my life is my responsibility."

\section{Discussion}

The way participants expressed gratitude was distinct at different ages. As a general rule, a decrease in the frequency of concrete gratitude and an increase of the connective type were found in older children. These results are similar to those of Baumgarten-Tramer's (1938) study, in which concrete gratitude appeared more frequently in 8-year-old children and connective gratitude appeared significantly more often in children 11 years and older.

The decrease in the frequency of concrete gratefulness with the advance of age can be interpreted as related to the decentration process. Since concrete gratitude is characterized by the repayment of a benefit valued by the child but not necessarily by the benefactor (repayment with a self-centered nature), it should be expected that, with development, this type of gratitude would diminish and, by contrast, connective gratitude would increase. For Baumgarten-Tramer (1938), together with children's mental development there is a better understanding of the social world; the feeling of gratitude has, therefore, a more advanced form of expression.

With the passage from concrete to formal thought, which occurs around 11 or 12 years, adolescents become capable of reasoning about hypotheses, and not only about observations of the real (Piaget \& Inhelder, 1955/1970). This qualitative transformation into this type of reasoning also causes changes in the affective and social life of 
human beings. For example, new possibilities of decentration appear. It is during the decentration process that children learn relativity on the physical plane and reciprocity on the social plane. Concrete gratitude features a certain degree of reciprocity, because children understand that they have to repay a favor. However, they think that what they value is also valued by the benefactor. In connective gratitude, by contrast, there is a more sophisticated reciprocity, because children understand that what is valued by them is not necessarily valued by the benefactor. So, in order to benefit their benefactor as they themselves had previously benefited, they have to repay with something that is valued by this prior benefactor. In this study, the evidence showed clearly that children 11 years or older were more likely to consider the benefactor's point of view in their answers, thanks to their capacity to understand that people do not always have the same tastes, needs and values as they themselves do.

However, throughout development, oscillations between centration and decentration occur (Piaget \& Inhelder, 1955/1970). Adolescence is the period in which the personality decenters from the self, but, in the face of any imbalance, it centers on itself again. In other words, despite formal operational thinking opening up new possibilities of decentration, adolescents are not immune to egocentrism, that is, to take their point of view as absolute. This explains, in part, why concrete gratitude was found among participants from 11 to 14 years of age.

On the other hand, some children younger than 11 also expressed connective gratitude, something previously reported by Baumgarten-Tramer (1938). Buck (2004) suggested that there is a kind of gratitude based only on the affective bond created between the beneficiary and the benefactor, which would not involve equity, reciprocity or obligation. This leads to the possibility that qualitatively distinct psychological processes may underly the same form of expressing gratitude. This is a hypothesis that needs to be investigated in future research.

Another issue to be investigated in future studies relates to variation in the frequencies of connective gratitude between 11 and 14 years of age (Figure 1). These studies could elucidate whether similar variation is found in other samples, or whether it was a particularity of this research sample.

Verbal gratitude appeared at all ages, as was the case in Baumgarten-Tramer's (1938) study. Among the answers classified in accordance with her categories $(89.1 \%$ of the total responses), $24.2 \%$ were solely of the verbal type. Moreover, in $26.3 \%$ of the cases the children and adolescents were concerned not only to repay the benefactor, but also said they would thank him or her verbally. This form of expressing gratitude seems to relate to the children's own learning. Since an early age, children have been encouraged by their parents and teachers to thank verbally whenever they receive a gift or some kind of help. In a study with 6- to 12-year-old children, La Taille (1998) observed that the idea of saying "thank you" because it is polite was the one that stood out at all ages. When asked if it was important to say thank you, all children had answered affirmatively, indicating that the value of a "thank you" remains throughout childhood. Baumgarten-Tramer (1938) hypothesized that verbal gratitude might be employed when children or adolescents do not know how to express what they feel. This idea seems reasonable. In this study, paralleling a high rate of verbal gratitude, we found a low rate of responses of the type "I don't know." It is possible that the participants expressed themselves through verbal gratitude when they did not know what to answer. However, BaumgartenTramer suggested that verbal gratitude could be interpreted in another way: sometimes it could be the way youngsters manifest a deep and genuine feeling of gratitude when they cannot find another way to express it. Due to our method - written answers - used in this study, it is not possible to distinguish among several possible meanings of this kind of gratitude.

Although Gordon et al.'s research (2004) had pointed to differences in the way boys and girls experience gratitude, with the former being more grateful for material objects and the latter to people, our study did not provide evidence of gender differences. This result is consistent with Paludo's study (2008), in which gender differences were not found in the expression of gratitude among children and adolescents at risk. Froh et al. (2009) also did not find empirical support for the hypothesis that girls would report more gratitude than boys.

The appearance of positive feelings (even in answers that did not fit into the established categories), strengthens the idea that a benevolent action generates this kind of feeling, a necessary, but not sufficient, condition for the emergence of gratitude (Bonnie \& de Waal, 2004; Piaget, 1965/1977).

The fact that finalistic gratitude was observed in only two answers can be related to the idea of self-sufficiency. Some participants wrote that they could develop, for instance, a professional career on their own. One can understand this as a manifestation of self-sufficiency stimulated by the social context, since, especially in contemporary Western culture, much emphasis is placed on independence and individualism (Arnett \& Taber, 1994; Halvorsen, 1998).

\section{Final Considerations}

The results of this study suggest that the expression of gratitude occurs differently across developmental stages, but similarly by gender. The hypothesis that gratitude develops over the course of childhood and adolescence was strengthened. We found that Baumgarten-Tramer's (1938) method was a useful means to investigate the ways in which children and adolescents express gratitude, not simply politeness.

However, there are still many gaps in our knowledge about the development of gratitude, thus necessitating 
more research on this subject. Gratitude seems to stimulate moral behavior, and may be an important factor in the construction of morality itself. Furthermore, it is a socially desired feeling that can contribute to individual wellbeing.

An important step that remains to be taken is to expand this study by analyzing the answers to the first question, too. Is it possible that a relation exists between what children and adolescents want (for example, material or non-material goods) and the manner in which they consider repaying someone for providing them?

In order to be considered as part of human development in general, it is necessary that a phenomenon is found in different cultural contexts (Flavell, 1982; Lourenço, 1992). Thus, it is crucial to conduct similar studies in other cultures. This research is currently in process in the United States, where data, including those relating to the first of Baumgarten-Tramer's questions, have recently been analyzed (Tudge $\&$ Freitas, 2011). The future goal is to include other countries (China, India, Mexico and Spain) in this research, attempting to discover similarities and differences found in different cultural contexts.

Elucidating in this manner issues associated with the development of gratitude can be helpful in the creation of programs designed to foster it, taking into account the point of view of children and adolescents while being, at the same time, sensitive to cultural differences. Encouraging developing individuals to be grateful for what they have and to those that benefit them is a way to reduce excessive consumerism, which is both turning life on our planet unsustainable, as well as exacerbating individualism, which is making it difficult to create community life based on mutual respect and justice.

\section{References}

Algoe, S. B., Haidt, J., \& Gable, S. L. (2008). Beyond reciprocity: Gratitude and relationships in everyday life. Emotion, $8(3), 425-429$

Arnett, J. J., \& Taber, S. (1994). Adolescence terminable and interminable: When does adolescence end? Journal of Youth and Adolescence, 23(5), 517-537.

Bartlett, M. Y., \& DeSteno, D. (2006). Gratitude and prosocial behavior: Helping when it costs you. Psychological Science, 17, 319-325.

Baumgarten-Tramer, F. (1938). "Gratefulness" in children and young people. Journal of Genetic Psychology, 53, 53-66.

Becker, J. A., \& Smenner, P. C. (1986). The spontaneous use of thank you by preschoolers as a function of sex, socioeconomic status, and listener status. Language in Society, 15, 537-546.

Bonnie, K. E., \& de Wall, F. B. M. (2004). Primate social reciprocity and the origin of gratitude. In R. A. Emmons \& M. E. McCullough (Eds.), The psychology of gratitude (pp. 213-229). New York: Oxford University Press.

Bono, G., \& Froh, J. J. (2009). Gratitude in school: Benefits to students and schools. In R. Gilman, E. S. Huebner, \& M. Furlong (Eds.), Handbook of positive psychology in schools (pp. 77-88). New York: Routledge.
Bono, G., \& McCullough, M. E. (2006). Positive responses to benefit and harm: Bringing forgiveness and gratitude into cognitive psychotherapy. Journal of Cognitive Psychotherapy, 20, 147-158

Bowles, S., \& Gintis, H. (2004). The evolution of strong reciprocity: Cooperation in heterogeneous populations. Theoretical Population Biology, 65(1), 17-28.

Buck, R. (2004). The gratitude of exchange and the gratitude of caring. In R. A. Emmons \& M. E. McCullough (Eds.), The psychology of gratitude (pp. 100-122). New York: Oxford University Press.

Castro, F. M. P., Rava, P. G. S., Hoefelmann, T. B., Pieta, M. A. M., \& Freitas, L. B. L. (2011). Deve-se retribuir? Gratidão e dívida simbólica na infância [Should one return a favor? Gratitude and symbolic debt in childhood]. Estudos de Psicologia (Natal), 16(1), 75-82.

Emmons, R. A., \& Shelton, C. M. (2002). Gratitude and the science of positive psychology. In C. R. Snyder \& S. J. Lopez (Eds.), Handbook of positive psychology (pp. 459-471). London: Oxford University Press.

Flavell, J. H. (1982). Structures, stages, and sequences in cognitive development. In W. Collins (Ed.), The concept of development (pp. 1-28). Hillsdale, NJ: Lawrence Erlbaum.

Freitas, L. B. L. (1999). Do mundo amoral à possibilidade de ação moral [From a non-moral world to the possibility of a moral action]. Psicologia: Reflexão e Crítica, 12(2), 447458.

Freitas, L. B. L. (2003). A moral na obra de Jean Piaget: Um projeto inacabado [The theory of morality in Jean Piaget's work: An unfinished project]. São Paulo, SP: Cortez.

Freitas, L. B. L., Silveira, P. G., \& Pieta, M. A. M. (2009a). Sentimento de gratidão em crianças de 5 a 12 anos [The feeling of gratitude in 5- to 12-year-old children]. Psicologia em Estudo, 14(2), 243-250.

Freitas, L. B. L., Silveira, P. G., \& Pieta, M. A. M. (2009b). Um estudo sobre o desenvolvimento da gratidão na infância [A study about the development of gratitude in childhood]. Revista Interamericana de Psicologia [Interamerican Journal of Psycholgy], 43(1), 22-29.

Froh, J. J. (2010, April). Teaching children how to think gratefully: Unveiling a new gratitude intervention for youth. In J. Tudge (Chair) \& S. Heubner (Discussant), The development of gratitude in children and adolescents. Symposium conducted at the Conference on Human Development, New York.

Froh, J. J., Kashdan, T. B., Ozimkowski, K. M., \& Miller, N. (2009). Who benefits the most from a gratitude intervention in children and adolescents? Examining positive affect as a moderator. The Journal of Positive Psychology, 4, 408-422.

Froh, J. J., Miller, D. N., \& Snyder, S. (2007). Gratitude in children and adolescents: Development, assessment, and school-based intervention. School Psychology Forum, 2, $1-13$.

Gintis, H. (2000). Strong reciprocity and human sociality. Journal of Theoretical Biology, 206, 169-179.

Gintis, H., Bowles, S., Boyd, R., \& Fehr, E. (2005). Moral sentiments and material interests: Origins, evidence, and consequences. In H. Gintis, S. Bowles, R. Boyd, \& E. Fehr (Eds.), Moral sentiments and material interests: The foundations of cooperation in economic life (pp. 3-39). Cambridge, MA: MIT Press. 
Gordon, A. K., Musher-Eizenman, D. R., Holub, S. C., \& Dalrymple, J. (2004). What are children thankful for? An archival analysis of gratitude before and after the attacks of September 11. Journal of Applied Developmental Psychology, 25(5), 541-553.

Graham, S., \& Barker, G. P. (1990). The down side of help: An attributional-developmental analysis of helping behavior as a low-ability cue. Journal of Educational Psychology, 82(1), 7-14.

Halvorsen, K. (1998). Symbolic purposes and factual consequences of the concepts "self-reliance" and "dependency" in contemporary discourses on welfare. Scandinavian Journal of Social Welfare, 7, 56-64.

Harris, P. L., Olthof, T., Meerum Terwogt, M., \& Hardman, C. E. (1987). Children's knowledge of the situations that provoke emotion. International Journal of Behavioral Development, 10(3), 319-343.

La Taille, Y. (1998). As virtudes morais segundo as crianças [Virtues according to children]. São Paulo, SP: Fundação de Amparo à Pesquisa do Estado de São Paulo.

La Taille, Y. de (2001). Desenvolvimento moral: A polidez segundo as crianças [Moral development: Politeness according to children]. Cadernos de Pesquisa, 114, 89-119.

La Taille, Y. de (2006). A importância da generosidade no início da gênese da moralidade na criança [The importance of generosity at the begining of moral development in childhood]. Psicologia: Reflexão e Crítica, 19(1), 9-17.

Lourenço, O. (1992). Para uma explicação piagetiana do aumento do altruísmo na criança: Alguns dados interculturais [Towards a Piagetian explanation for the increase in children's altruism: Some cross-cultural data]. Revista Portuguesa de Pedagogia, 26(2), 301-319.

Lourenço, O. M. (2000). The aretaic domain and its relation to the aretaic domain in moral reasoning. In M. Laupa (Ed.), Rights and wrongs: How children and young adults evaluate the world (pp. 47-61). San Francisco: Jossey-Bass.

Lyubomirsky, S., Sheldon, K. M., \& Schkade, D. (2005). Pursuing happiness: The architecture of sustainable change. Review of General Psychology, 9, 111-131.

McCullough, M. E., Tsang, J., \& Emmons, R. A. (2004). Gratitude in intermediate affective terrain: Links of grateful moods with individual differences and daily emotional experience. Journal of Personality and Social Psychology, 86, 295-309.

Miller, D. N. (2006). Cultivating an attitude of gratitude: Thanksgiving thoughts for school psychologists. Cотmuniqué, 35(3), 5-6.

Paludo, S. S. (2008). Emoções morais e gratidão: Uma nova perspectiva sobre o desenvolvimento de jovens que vivem em situação de risco pessoal e social [Moral emotions and gratitude: A new perspective on youths who live at personal and social risk]. Retrieved April 24, 2010 from http:// hdl.handle.net/10183/14289

Piaget, J. (1954). Les relations entre l'affectivité et l'intelligence [Relations between affectivity and intelligence]. Paris: Sorbonne.

Piaget, J. (1977). Études sociologiques [Sociological studies] (3 ed.). Genève, Suisse: Droz. (Original work published 1965)

Piaget, J. (1992). Le jugement moral chez l'enfant [The moral judgment of the child] (7 ed.). Paris: Presses Universitaires de France. (Original work published 1932)
Piaget, J., \& Inhelder, B. (1970). De la logique de l'enfant à la logique de l'adolescent: Essai sur la construction des structures opératoires formelles [The growth of logical thinking from childhood to adolescence: An essay on the construction of formal operational structures] (3 ed.). Paris: Presses Universitaires de France. (Original work published 1955)

Pieta, M. A. M., \& Freitas, L. B. L. (2009). Sobre a gratidão [On gratitude]. Arquivos Brasileiros de Psicologia, 61, 100108.

Russell, J. A., \& Paris, F. A. (1994). Do children acquire concepts for complex emotions abruptly? International Journal of Behavioral Development, 17(2), 349-365.

Seligman, M. E. P., Steen, T. A., Park, N., \& Peterson, C. (2005). Positive psychology progress: Empirical validation of interventions. American Psychologist, 60, 410-421.

Sheldon, K. M., \& Lyubomirsky, S. (2006). How to increase and sustain positive emotion: The effects of expressing gratitude and visualizing best possible selves. Journal of Positive Psychology, 1, 73-82.

Simmel, G. (1950). The sociology of Georg Simmel. Glencoe, IL: Free Press.

Smith, A. (2002). Teoria dos sentimentos morais [Theory of moral sentiments] (L. Luft, Trad.). São Paulo, SP: Martins Fontes. (Original work published 1759)

Tsang, J. (2006). Gratitude and prosocial behavior: An experimental test of gratitude. Cognition and Emotion, 20(1), 138148.

Tsang, J. (2007). Gratitude for small and large favors: A behavioral test. The Journal of Positive Psychology, 2, 157167.

Tsang, J. A., \& McCullough, M. E. (2004). Annotated bibliography of psychological research on gratitude. In R. A. Emmons \& M. E. McCullough (Eds.), The psychology of gratitude (pp. 291-295). New York: Oxford University Press.

Tudge, J., \& Freitas, P. (2011, May). What do children and adolescents want? The relations between materialism and gratitude. Poster presented at the Norte e Nordeste Congresso de Psicologia, Salvador, BA.

Watkins, P. C., Woodward, K., Stone, T., \& Kolts, R. L. (2003). Gratitude and happiness: Development of a measure of gratitude, and relationships with subjective wellbeing. Social Behavior and Personality, 31, 431-452. 